\title{
POTENTIAL CLUSTERS IN BANAT AND THEIR ROLE IN REGIONAL ECONOMIC DEVELOPMENT
}

\author{
Ramona IŞFĂNESCU \\ West University of Timişoara, Romania
}

\begin{abstract}
The interest in the study of clusters and their role in the economic development of certain regions has constantly grown in the past years. This interest has also been emphasized by the emergence of successful clusters in many regions; these are clusters that have visibly and they have determined the increase in competitiveness of those particular regions. Clusters are geographic gatherings of firms and institutions, connected to each other and specialized in certain fields of activity. In Romania, due to the low cooperation level among enterprises we cannot say that proper clusters exists, but jus some "spatial gatherings" of firms activating in certain domains, connected by the need of using certain natural resources and the existence of a specialized workforce in that particular domain. Natural "clusters" can be identified by means of quantitative analyses, these indicating the possibility to identify certain spatial assemblies of firms in a certain economic sector. Starting from these quantitative analyses, for Banat region have been identified some important spatial gatherings of firms activating in certain domains which could represent potential clusters in this area. As clusters function on the principle of cooperation among enterprises, a strong point of the region is the presence of foreign investors which promoted the model of enterprise cooperation through sub-contracting local enterprises. Among these, we mention the Italian investors which brought to Banat, especially to Timiş County the Italian cluster model. Are there in Banat premises for the emergence of clusters? Which are the fields of activity in which these clusters can emerge? What role will these clusters play in the economic development of the region? These are just some of the questions that we aim answering to through this study.
\end{abstract}

Key Words: entrepreneurial initiative, spatial gatherings of firms, clusters, economic development, Banat, Romania.

\section{The concept of cluster}

According to the definition of Michael Porter (1998), clusters are "geographical concentrations of firms and institutions, in interconnection, that activate in a certain field of activity $^{\prime 1)}$. Together with many firms that cooperate, inside the clusters can be found governmental bodies and educational institutions, training centers for professionals, employers' associations etc. So, there are producers, providers, researchers, partners or even competitors inside the same industrial branch, which have their businesses in the region. The cluster can be located in every type of territorial community, from the smallest (towns, groups of communes), to large regions inside a state, the entire territory of a state, or border regions between states.

The experience of developed countries shows that cluster processes serve as a base for constructive dialogue between the people in the entrepreneurial and state environment, educational, information environments, nongovernmental associations etc. They allow

1) M. Poter, Clusters and the new economics of competition, Harvard Business Review, Boston, novemberdecember, 1998, p. 78. 
increasing the efficiency of relations inside the innovation processes from the private, state, commercial associations, educational institutions and research sectors. These cooperative relationships are beneficial first of all for the firms, because they help improving their performances, becoming more competitive. Moreover, cluster development in a region contributes to its specialization in the respective fields, which will become dominant and technologically advanced. (Fig. 1). Although there are competitive relationships between firms, being specialized on similar types and varieties of products, the development of parallel cooperation relationships gives them an advantage in terms of competitiveness through diffusion of innovation from one firm to all the others' that form the cluster. Thus, an optimum of competition - cooperation balance is created between the local firms, which will lead to competitive advantages for the whole cluster. As for the role of clusters in supporting a region in its competition with another region, M. Porter (1998), differentiated three ways in which to achieve this: by increasing the productivity of the companies inside that region; by establishing the direction and rhythm of innovation, which will influence the future productivity; by stimulating the creation of new businesses, which would develop and strengthen the cluster.

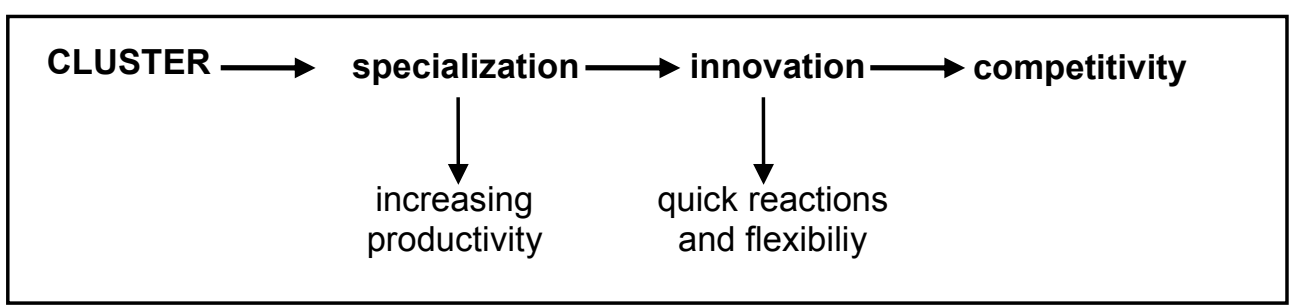

Fig. 1 - Clusters and their role in the development of a region

Clusters have a positive influence not only on innovation and competitiveness, but also on the increase of business dynamics on a long term. Integrated in a network, the companies have greater chances of survival in a competition environment, than if they were to remain isolated.

\section{Premises of cluster apparition in Banat}

Due to the low level of cooperation between firms, we cannot talk about clusters in Romania, only about "spatial agglomerations" of firms in a certain domain, tied to the dominance of natural resources and the existence of a specialized population in that field. These are "natural" clusters, which can be identified based on quantitative analysis. Together with "natural clusters", there are also the so-called "public" clusters, which are agglomerations of firms resulted from public policies. By law, these have the status of industrial parks, scientific and technological parks. If in the case of scientific and technological parks, there is a partnership between firms and educational/research institutions, industrial ones are most of the times just an agglomeration of firms which do not cooperate, but only share the infrastructure offered inside the park ${ }^{2}$. The difference between "natural" and "public" clusters is the fact that natural ones occurs spontaneously, over time, while the latter are the result of public policies.

The research has shown that in Romania clusters have crystallized in domains such as software, naval industry, wood industry, textile industry, ceramics and shoe industry.

A possible methodology to identify and analyze potential clusters in a region would have the

2) Pîslaru D., Prospects and challenges for cluster development - possibilities for implementing the cluster model in Romania, in "Clusteri de întreprinderi şi internaționalizarea IMM-urilor. Cazul zonei Timişoara, România", Timişoara, 2004, p. 1. 
following steps:

- $\quad$ identifying spatial concentrations of companies in certain fields of activity (based on quantitative analysis);

- $\quad$ identifying traditional industrial sectors;

- analyzing the level of endogenous entrepreneurial development, based on the traditional local production (the emergence of some small and medium-sized enterprises in tight relation with the natural resources of the area);

- $\quad \mathrm{ISD}^{3)}$ analysis in the region, which led to the development of small and medium-sized enterprises with cooperation between firms and subcontracting relationships and to the development of sectors of activity preferred by the foreign investors;

- $\quad$ identifying the relations that exist between firms inside the potential cluster, relations between different categories of firms, from the raw materials providers to the production, distribution firms, as well as firms that promote courses for professional forming in on field or another;

- $\quad$ identifying the institutions that capable of developing the economic infrastructure and which provide services to local companies (universities, research and innovation centers, banks, consulting centers etc).

Starting from this methodology and using mostly quantitative analysis, there have been identified in Banat important concentrations of firms in several fields of activity, which could represent potential clusters.

An important factor that generated the developing of incipient collaborative relationships between firms has been the presence of a high number of foreign investors in Banat, which has positively influenced the emergence of companies with between-firms cooperation characteristics. From these, a decisive role went to the Italian investors, which brought especially in Timis county, the model of "industrial district", which is the Italian model for cluster. The fact that most of the Italian investments come from the Italian region of Veneto contributed to facilitating the social process of cohesion of Italian entrepreneurs ${ }^{4)}$. Practically, the internationalization of Italian firms came with the relocation of the pre-existent networks in Italy, thus allowing the transfer of knowledge in the newly formed network. Gradually, local firms began to be included in the network, through subcontracting. The tendency to subcontract of the Italian firms played an important role in spreading the entrepreneurial culture in the region, which, correlated with the high initiative spirit of the Banat inhabitants, contributed to the emergence of some small and medium-sized enterprises (SMEs) with Romanian capital, some of them becoming important links inside the forming of clusters.

The presence of raw materials resources (wood, crops, construction materials etc), of a specialized workforce in various domains, of sectors of activity with tradition in Banat (textiles, chemicals) and new sectors (high tech, IT, communications), which in the last few years had a considerable development, also represent important factors in developing successful clusters in this region. For a cluster to function and become competitive, together with the firms that form it, other regional actors also play an important role, they must have the ability of developing the regional economic infrastructure and stimulating the entrepreneurial potential. In Banat, such institutions are: universities (at Timişoara, Lugoj, Reşita), research centers, consulting centers, financial and banking institutions, commerce chambers at every county level, other

3) ISD = direct foreign investments

4) A. Majocchi, Dezvoltarea unui mediu de afaceri favorabil: din experiența firmelor italiene din regiunea Timişoara, România, în vol. „Clusteri de întreprinderi şi internaționalizarea IMM-urilor. Cazul zonei Timişoara, România", Timişoara, 2004, p. 9. 
organizations of business environment (ADR West, ADECS, ADETIM, Euro-Info centers, OTIMM Timişoara) $)^{5}$. All these are only a few of the premises of the emergence and development of important clusters in Banat.

\section{Potential clusters in Banat}

Based on specific statistics, for the potential development of clusters: high percentage of firms in certain fields of activity, local raw resources, the high rate of employment in those fields, a large number of new small and medium-sized enterprises, the turnover in one sector compared to that in another, the existence of support institutions, it has been reached the conclusion that at Banat and especially Timiş county level, it is possible that clusters may form in the future, in the following domains: wood industry, textiles, shoes and software and electronics.

Potential cluster in the wood industry. The rich forest resources in quantity and quality (over $550000 \mathrm{ha}$ ), the tradition in wood processing and the spatial concentration of companies in this domain ( 1900 enterprises) represent important premises in the apparition of a cluster. The presence of cheap workforce and the important forests resources attracted foreign investors, with a notable role in the creation of the first network of companies. In most cases, in these networks, local people are occupied with cutting and primary processing of wood and the foreign investors bring the technology and know-how in processing the wood and producing goods with high added-value for the external market. From the total of active companies, over $71,9 \%$ are concentrated in the primary processing of wood and only $28,1 \%$ in the furniture industry. If the companies in the first category have a high degree of dispersion, related to the existence of the raw materials, furniture industry is concentrated especially in those localities where there is an important market for selling it and the possibility of quick access through major communication routes, to international markets.

An analysis of the territorial distribution of small and medium-sized enterprises in the field of wood processing shows a strong concentration in the mountain area which has important forest resources. Many localities from the Almăjului Depression (Bozovici, Prigor, Dalboşeț, lablanița), from the Timiş - Cerna - Bistra Corridor (Mehadia, Teregova, Armeniş, Zăvoi), from the western part of the Poiana Ruscă Mountains (Pietroasa, Tomeşti, Nădrag) or the Făget Depression (Margina, Mănăştiur, Făget), have saws for cutting logs, or small companies that produce elements of carpentry, wood packaging and other products (Fig. 2).

In many of these settlements, the activities in the wood processing field are the only initiatives in the productive sector. Practically, there is a permanent cooperation between the firms here, the ones that are working in the primary processing and the ones that produce furniture, veneer and plywood. Together with the existing firms, with an important role in developing a successful cluster, are the institutions that offer services to the companies and are taking care of the professional training of the future employees. Among these are: schools (Forest School Group Caransebeş, Forest School Group Timişoara, School Group "Traian Grozăvescu" Nădrag, "Romulus Paraschivoiu" School Group from Lovrin, The school of Arts and Handcrafts from Prigor) and universities (The Faculty of Horticulture from the Banat University of Agricultural Sciences and Veterinary Medicine Timişoara), with specializations in this field, but also other institutions, that sustain the entrepreneurial phenomenon at regional level.

5) $A D R$ West $=$ West Regional Development Agency; $A D E C S=$ Economic Development Agency of Caraş-Severin County; ADETIM = Economic Development Agency of Timiş County; OTIMM Timişoara = Territorial Office for Small and Medium-Sized Enterprises and Cooperation of Timisoara, which coordinates the activity of SMEs and cooperation societies in Timiş, Caraş-Severin, Arad, Hunedoara and Bihor counties. 


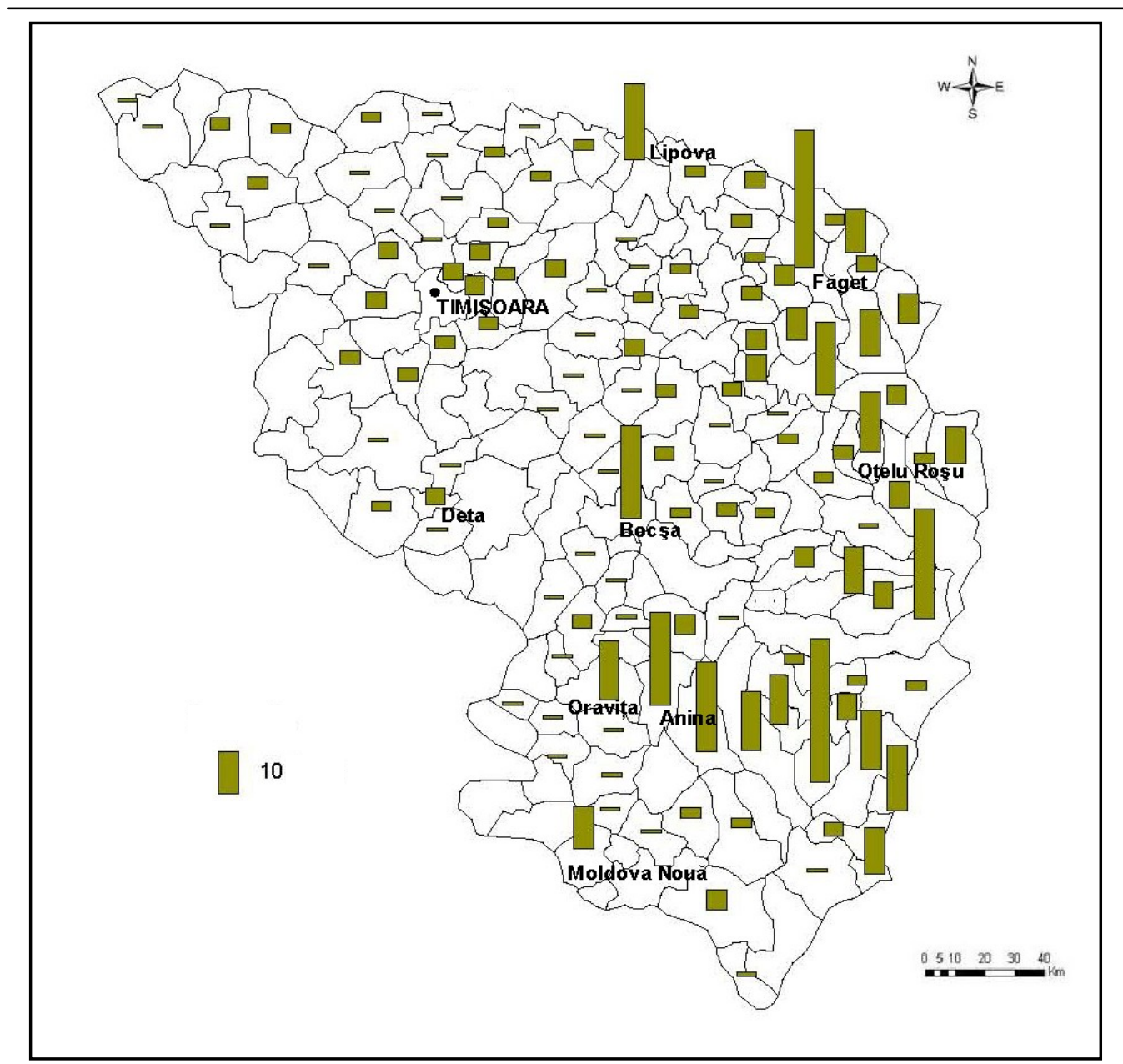

Fig 2 - The repartition of the firms from the primary wood processing field in Banat (2005) (except big and medium cities)

Potential cluster in footwear industry. Specialized workforce and the tradition in processing leather and making footwear have been important factors in the apparition and development of private initiatives in this field, after 1989. This domain attracted numerous investors, especially Italians. Having the "Italian district" as a model, they created many small and medium-sized enterprises, especially in the urban areas, in centers with tradition in this field, where in the communist were functioning many factories of this kind (Timişoara, Lugoj), or decentralized sections of these (Buziaş, Recaş, Jimbolia). Under the circumstances of the restructuring of the big footwear companies and the presence of available workforce, the Italians' businesses had a real success in the '90's. The new companies with Italian capital are in fact the result of transferring in Banat production activities with low added value, the main reason being the cheap workforce. Today, these firms collaborate with leader companies from Italy and less with the ones in Banat, but in the future, in the situation of creating excellence centers in the region, that will add value, local cooperation networks can appear. Usually, the companies in this 
domain of activity create intensive business relations, leading to the shaping of a successful cluster. In a cluster there must always be leader-companies, capable of mobilizing the rest of the companies in the cluster.

The geographical concentration of the firms in this field, especially the small and medium ones, is an important step in the creation of a cluster. In 2005, the total number of companies in the footwear industry was 176 , from which $23.8 \%$ with foreign capital. There is a strong concentration of companies in Timiş county (84.1\%), especially in Timişoara (42\%) and Lugoj $(10 \%)$ (Fig 3). In the communist era, Timişoara was the second center of this industry after

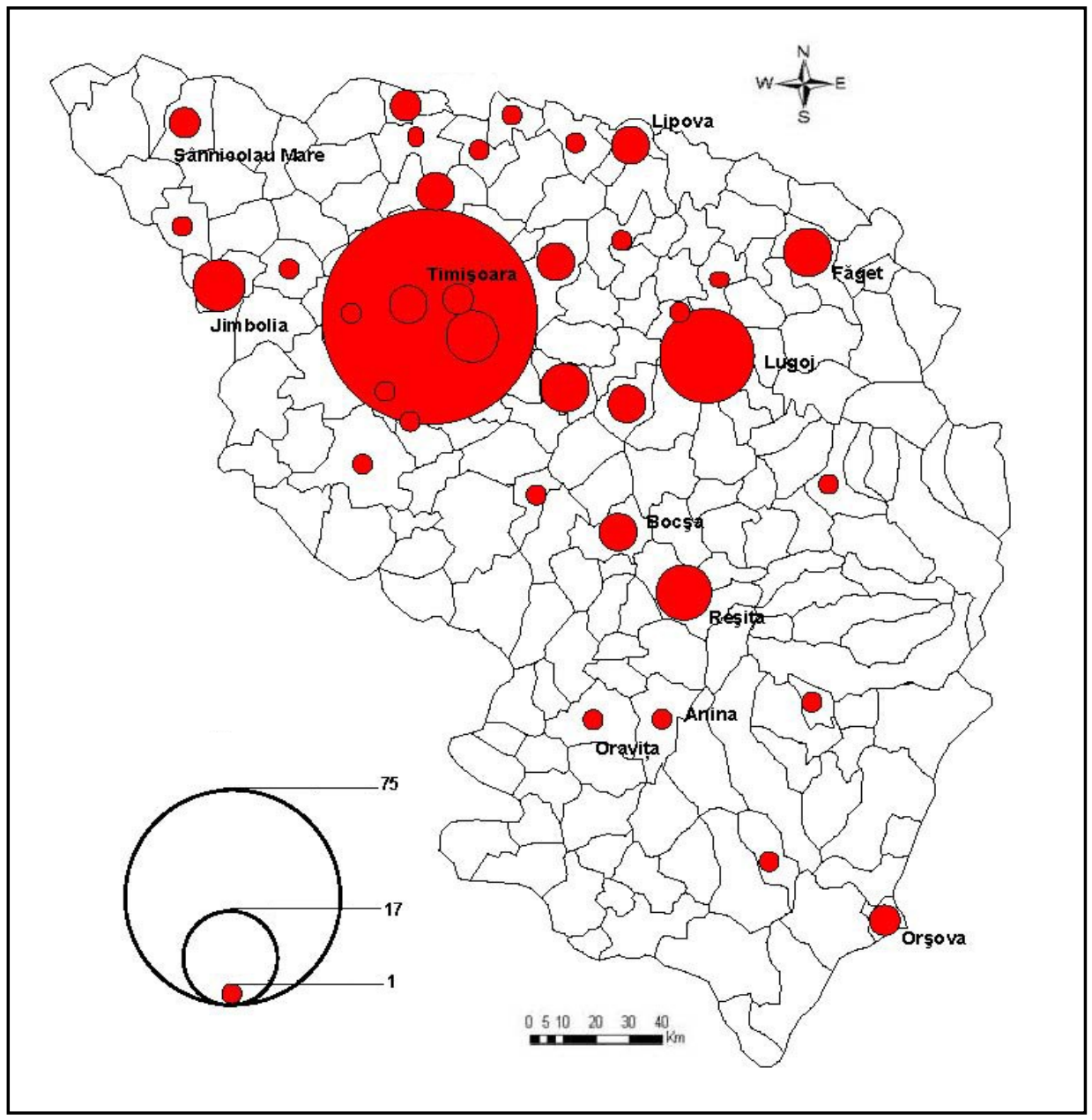

Fig.3 - Territorial repartition of the firms in footwear industry, in Banat (2005)

6) Founded in 1900, the shoe factory "Turul" was considered one of the most modern factories in the Austrian - Hungarian Empire, with over 130 branches in Hungary, Germany, Switzerland, England, Holland, France, USA etc. (after I. Munteanu, Rodica Munteanu, Timişoara: monografie, Editura Mirton, Timişoara, 2002, p.272). 
Bucharest, names like "Guban", "Filty", "Otter" being associated with the name of the city. Tradition companies functioned here: "Banatul" footwear factory (mentioned in 1900 under the name "Turul"6) ), "Modern" footwear factory (created in 1921 under the name "Lux"), Guban etc. Today, some of them (Guban, Banatul) have considerably reduced their activity, or even closed (Modern), leaving a high number of unemployed, which were hired by the new small and medium-sized enterprises. Initiatives appeared in some small towns as well (Jimbolia, Recaş, Făget, Buziaş), by taking sections that belonged to the old state companies.

Only $15,9 \%$ of the total number of firms are located in Caraş-Severin county, especially in Reşita (4\%) and Bocşa (2\%), as well as in other urban centers, with available workforce. This branch still plays a secondary role, compared to the other traditional industries (mining, steel, machine construction, wood processing). In the Banat rural space, most of the firms are placed near Timişoara (Dumbrăvița, Moşnița Nouă, Giroc).

In the light of the things presented, we can draw the conclusion that in Banat, especially in the Timiş county, all the conditions are met for a cluster in the footwear industry to form, even more so because there also exists cooperation between the firms and the institutions that are into education and farming sectors. In five cities (Timişoara, Reşita, Deta, Lugoj şi Sânnicolau Mare), in the high school curricula there are specializations in textiles and leather processing, with a total of 150 places a year. Also, an important link in this cluster could be the ones that are into farming, because they can supply part of the raw material. Today, these relations are incipient, many firms importing their raw material.

Potential cluster in the textile industry. The high number of textile firms (approx 480), their concentration mostly in Timiş county, the presence of many Italian investors, which brought the Italian cluster model, transferring the know-how to the new firms, the implication of many institutions in sustaining the entrepreneurial phenomenon in this field are important premises for the development of a cluster in the textile industry.

The important concentration of companies in the Timis county $(75.8 \%)$, especially in Timişoara $(58 \%)$, in the proximity of Timişoara (Sânandrei, Ghiroda, Giarmata, Dumbrăvița, Săcălaz), and Lugoj (4\%), appeared in correlation with the traditional centers in this space (Fig. 4).

During the communist period there were many factories in Timisoara, some of them with a long history, which after 1989 underwent a restructuring process, some of them even being closed. The resulting available workforce, its reduced cost and the possibility of using already existent production spaces have attracted a high number of investors.

In Caraş-Severin County, most of the factories are concentrated in Reşita (14\%), but they are spread in all the urban centers, the interest of the investors being to integrate and use the available feminine workforce, given the fact that traditionally, in this county, the dominant is the heavy industry.

Considering the fact that this industry is based on processing considerable amounts of raw materials (natural and artificial), it could contribute to the creation of more firms, enlarging the network. The usage of traditional materials (wool, flax etc) would stimulate initiatives in agriculture (sheep farming, textile plants cultivation) and would contribute to strengthening the relations inside the cluster. The use of synthetic fibers and wires, could determine the emergence of relationships with factories that produce these materials.

Potential cluster in software and electronics. Activities in the sectors of software and 


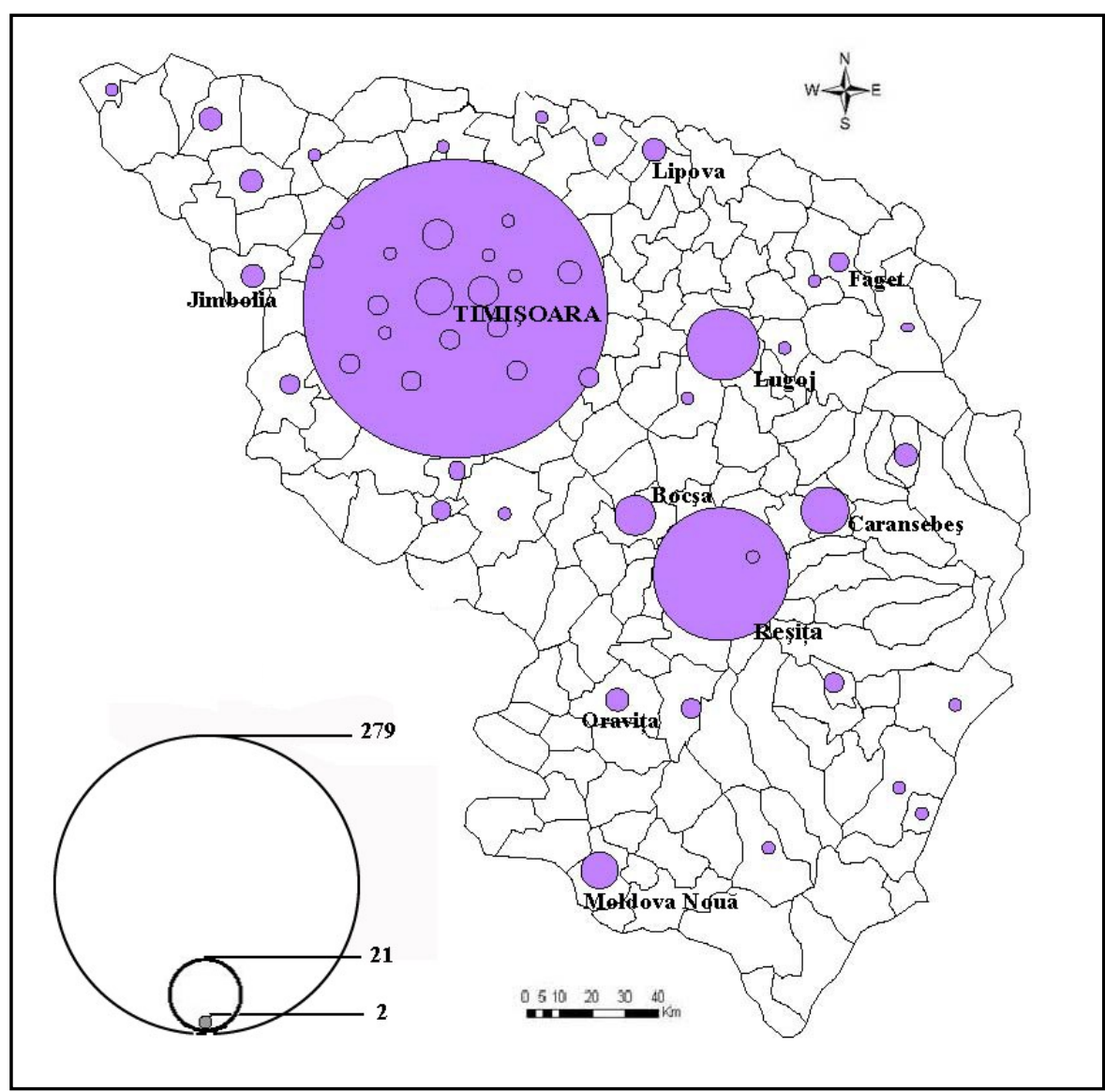

Fig. 4 - Territorial repartition of the textile industry firms in Banat (2005)

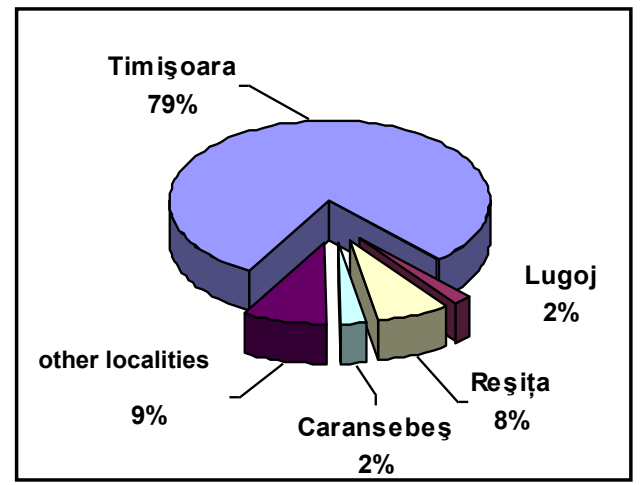

Fig. 5 - The distribution of software companies in Banat (2005)

electronics have had, since the '90's, a real success. The presence of "Politehnica" University of Timişoara, which is one of the biggest and most well-known technical universities from 
Central and Eastern Europe, and a high number of specialists have been at the base of the spectacular increase of number of the entrepreneurial initiatives in this field. Alongside small firms that appeared as a result of initiatives of former Politehnica students, in Timişoara there are also well-known foreign companies (Alcatel, ABB Rometrics, Siemens, Solectron etc).

The concentration of more than $75 \%$ of the firms in Timişoara, the existence of a highly qualified workforce, the developing of a Business Incubator and a Technology Transfer Center in software, the existence of a relation partnership between firms and the "Politehnica" University of Timişoara are important premises in forming a successful cluster (Fig. 5). The role of the Business Incubator is to support the creation and development of small firms founded by the students and young graduates, because, although in Timişoara we can find headquarters of prestigious software firms, they do not have the capacity to absorb the existent IT specialists. The creation of new firms would have the role of strengthening the cluster.

\section{Conclusions}

The present analysis underlines the fact that, from the spatial concentrations of companies in the same field of activity to the future clusters there is a small step, if the companies can create the cooperation relations between them and with other regional and local institutions. The development of clusters in Banat will play an important part in the economic growth of the region, on one hand, but will also sustain the entrepreneurial phenomenon, on the other hand. Clusters are environments suited for information, communication, innovation, cooperation in business, offering a higher range of opportunities to small and medium-sized enterprises as a collectivity on important markets than individual companies do. There is more and more evidence to support the fact that small and medium-sized enterprises are confronted with difficulties not because of their size, but because of their isolation.

\section{Bibliography}

BENKO G., LIPIETZ A. (1992), Les régions qui gagnent. Districts et réseaux: les nouveaux paradigmes de la géographie économique, PUF, Paris.

BIZAGUET A. (1993), Petites et moyennes entreprises, Collection Que sais-je ?, PUF, Paris.

COOKE P., MORGAN K. (2000), The associational economy: firms, regions and innovation, Oxford University Press, New York.

IANOŞ I. (2000), Potențialul economic al teritoriului şi dezvoltarea sectorului antreprenorial în România, Rev. Terra, nr.2, p. 64 -70.

IŞFĂNESCU Ramona (2006), Arii de concentrare şi dispersie a IMM-urilor în Banatul românesc, Comunicãri de geografie, Vol. X, Bucureşti., p. 351-356.

MUNTEANU I., MUNTEANU Rodica (1998), Timiş-monografie, Editura Marineasa, Timişoara, $350 \mathrm{p}$.

PÎSLARU D. (2004), Prospects and challenges for cluster development - possibilities for implementing the cluster model in Romania, in "Clusteri de întreprinderi şi internaționalizarea IMM-urilor. Cazul zonei Timişoara, România”, Timişoara.

POPA N. (2006), Le rôle des réseaux des PME dans le développement régional: le cas des investissements italiens dans le Banat roumain, Geographica Timisiensis, vol.XV, nr.1-2, Timişoara, p.5-21. 


\section{Ramona IŞFĂNESCU}

POPA N., BIOTEAU E., PAVEL S., IŞFĂNESCU Ramona, (2008), Banatul. Identitate, dezvoltare, colaborare regională, Editura Mirton, Timişoara, 217p.

PORTER M. (1998), Clusters and the new economics of competition, Harvard Business Review, Boston, p.77-90.

Received at : 26.11 .2009

Revised at: 18.02.2010

Accepted for publication at: 3.04.2010 